\title{
Bir TÜBİTAK Bilim Fuarına Katılan Öğrencilerin Fizik Dersine Yönelik Tutumlarındaki Değişimin İncelenmesi
}

\author{
Sultan ÇAĞAN \\ Milli Eğitim Bakanlığ1 \\ incilers@hotmail.com \\ Dasan Şahin KIZILCIK \\ Gazi Üniversitesi \\ hskizilcik@gazi.edu.tr \\ Pervin ÜNLÜ YAVAŞ \\ Gazi Üniversitesi \\ pervinunlu@gazi.edu.tr
}

Gönderilme Tarihi: 20/12/2019

Kabul Tarihi: $10 / 07 / 2020$

Yayınlanma Tarihi: 29/07/2020

DOI: $\underline{\underline{10.30855 / g j e s .2020 .06 .02 .001}}$

\begin{tabular}{|c|c|}
\hline Makale Bilgileri & ÖZET \\
\hline $\begin{array}{l}\text { Anahtar } \\
\text { Kelimeler: } \\
\text { Bilim fuarı, } \\
\text { Fizik dersi, } \\
\text { Tutum }\end{array}$ & $\begin{array}{l}\text { Bu çalışmanın amacı, bir TÜBİTAK Bilim Fuarına katılan öğrencilerin } \\
\text { fizik dersine karşı tutumlarının değişimini incelemektir. Bu çalışmada, } \\
\text { nicel araştırma yöntemlerinden biri olan deneysel yöntemle } \\
\text { gerçekleştirilmiştir. Araştırmacılar tarafından geliştirilmiş Likert } \\
\text { türündeki } 28 \text { maddeden oluşan Fizik Dersi Tutum Ölçeği ile TÜBİTAK } \\
\text { Bilim Fuarlarına katılan öğrencilerin tutumlarındaki değişim } \\
\text { incelenmiştir. Araştırmada ilgi, kaygı önem ve özyeterlik } \\
\text { faktörlerinden oluşan fizik dersine yönelik tutum ölçeği kullanılmıştır. } \\
\text { Ölçek TÜBİTAK Bilim Fuarı ile ilgili ön hazırlık çalışmaları başlamadan } \\
\text { dört ay kadar önce ve fuardan bir hafta sonra, bir fen lisesinde öğrenim } \\
\text { gören } 33^{\prime} \text { ü kadın, } 59^{\prime} \text { 'u erkek, toplam } 92 \text { lise öğrencisine uygulanmıştır. } \\
\text { Sonuç olarak, öğrencilerin genel tutumlarında olumlu yönde bir } \\
\text { değişim olmasına karşın, yalnızca kaygı boyutundaki değişim } \\
\text { istatistiksel olarak anlamlı düzeydedir. Ön test ve son test arasında } \\
\text { cinsiyet açısından kadın öğrencilerin lehine “Önem”, sınıf düzeyi } \\
\text { açısından ise “İlgi” ve “Önem” faktörlerinde üst sinıfların lehine anlaml } \\
\text { değişim olduğu görülmüştür. }\end{array}$ \\
\hline
\end{tabular}

Çağan, S., Kızılcık, H. Ş., \& Ünlü Yavaş, P. (2020). Bir TÜBİTAK bilim fuarına katılan öğrencilerin fizik dersine yönelik tutumlarındaki değişimin incelenmesi. Gazi Eğitim Bilimleri Dergisi, 6(2), 168184. DOI: https://dx.doi.org/110.30855/gjes.2020.06.02.001

Dergi Web Sayfasi: http://dergipark.gov.tr/gebd 


\section{Investigating the Change of Attitudes Towards Physics Courses of Students That Participate in a TUBITAK Science Fair}

\begin{tabular}{|c|c|}
\hline Article Info & ABSTRACT \\
\hline $\begin{array}{l}\text { Keywords: } \\
\text { Science fair, } \\
\text { Physics course, } \\
\text { Attitude }\end{array}$ & $\begin{array}{l}\text { The aim of this study is to investigate the change in the attitudes of } \\
\text { physics courses of the students participating a TÜBITAK Science Fair. } \\
\text { In this study, quantitative research techniques were used. The study was } \\
\text { carried as a quasi-experimental model. The research examines the } \\
\text { attitudes of the students participating in TÜBITAK Science Fairs with } \\
\text { Attitude Scale for Physics Course consisting of } 28 \text { items in Likert type } \\
\text { developed by the researchers. Attitude scale for physics courses } \\
\text { consisting of interest, anxiety, importance and self-efficacy factors were } \\
\text { used. This scale was applied to a total of } 92 \text { high school students, } 33 \\
\text { female and } 59 \text { male students who were studying at a science high school } \\
\text { four months before and after the TUBITAK Science Fair. As a result, } \\
\text { there is a positive change in general attitudes of students but only the } \\
\text { change in the factor of anxiety is statistically significant. Between the } \\
\text { pre-test and the post-test, there was a significant change in favor of the } \\
\text { female students in terms of "Importance" and in favor of the upper } \\
\text { grade students in terms of "Interest" and "Importance". }\end{array}$ \\
\hline
\end{tabular}

\section{Gíriș}

TÜBİTAK Bilim ve Toplum 4006 Bilim Fuarları, ortaöğretimde bilim kültürünün geliştirilmesine yönelik olarak Milli Eğitim Bakanlığına bağlı devlet okulları, Mesleki Eğitim Merkezleri ve Bilim ve Sanat Eğitim Merkezlerinde düzenlenen, TÜBİTAK tarafından uygun görülen alt projelerin sergilendiği etkinlikler olarak tanımlanmıştır. Bu fuarların amacı, 5-12. sınıf öğrencilerinin; öğretim programları ve kendi ilgileri doğrultusunda belirledikleri konular üzerine araştırma yapacakları, bu araştırmaların sonuçlarını sergileyebilecekleri, öğrencilerin ve izleyicilerin eğlenerek öğrenebilecekleri bir ortam oluşturulması olarak belirtilmiştir (TÜBİTAK, 2018). TÜBİTAK 4006 Bilim Fuarı, sayısal ve sözel alanlarda toplam yirmi bir alandan en az üç tanesini kapsayacak, araştırma, inceleme ve tasarım türlerine uygun projelerden oluşur. Bilim fuarına katılan öğrenciler, danışmanları ile birlikte iki ay süren çalışmaları sonunda sunumları gerçekleştirir.

Genel olarak bilim fuarları, öğrencilerin bilimsel projeleri için, araştırma sorusu ve yöntemi oluşturma, bulguları elde etme, sonuçları sunma ve tartışma gibi eylemlerini kapsar (TÜBİTAK, 2018). Bilim fuarlarının öğrencilerin bilime ilgisini arttırmak, problem çözme ve eleştirel düşünme becerilerini geliştirmek gibi katkıları vardır. Bilim fuarları, bilimsel araştırma yöntemlerinin öğrencilerce öğrenilip uygulanmasını sağlamakta, birlikte çalışmalarını teşvik etmektedir (TÜBİTAK, 2018). Ayrıca bilim şenliklerinin öğrencilerin problem çözme becerilerini 
olumlu yönde etkilediği görülmektedir (Yıldırım, 2018). Ayrıca bu tür fuarlara izleyici olarak katılanlar da fuarda görev alan öğrencilerin fizik dersine karşı olumlu tutum geliştireceklerini düşünmektedirler (Kızılcık, Çağan, Ünlü Yavaş, 2018). Rahm, Martel-Reny ve Moore (2005), okul sonrası yapılan bilim aktivitelerinin sosyal ve kültürel rolüne dikkat çekmiş ve özellikle düşük gelirli gençlerin bilimle anlamlı bir bağ kurmasına ve gelecek eğitimlerinde umutlu olmalarına faydalı olduğunu belirtmiştir. Bu tür etkinlikler, öğrencilerin meslek seçimlerini de etkileyebilmektedir. Amerika'da yapılan bir diğer araştırmanın sonuçları, okul sonrası yapılan Fen, Teknoloji, Mühendislik ve Matematik (FeTeMM) etkinliklerinin öğrenciler arasında oldukça popüler olduğunu, öğrencilerin meslek seçiminde FeTeMM alanlarına yönelik ilgiyi arttırdığını ve iletişim ve işbirliği gibi 21. yüzyıl becerilerini geliştirmesine katkıda bulunduğunu göstermektedir (Şahin, Ayar ve Adıgüzel, 2014). Bilim fuarları öğrencilerin bilimsel uygulamalara katılımını geliştirirken aynı zamanda bilim insanı kimliği geliştirmelerine de imkân vermektedir (Koomen, Rodriguez, Hoffman, Petersen ve Oberhauser, 2018). Bilim fuarı ve şenliklerinin, öğrencilere olumlu katkısı olduğu çeşitli çalışmalarla gösterilmiştir. Öğretmenlere göre bilim fuarlarında, öğrencilerin yaptıkları sunumlarda kullandıkları günlük bilimsel konuşmaların temel fen kavramlarını öğrenmelerine katkısı bulunmaktadır (Gomez, 2007). Bilim fuarına danışman olarak katılan öğretmenler, bilim fuarlarının amacına hizmet ettiğini düşünmektedir (Avcı ve Su Özenir, 2018). Bu araştırmaya katılan öğretmenler, fuar sürecinin, öğrencilerin araştırmaya yönelik ön hazırlık yapabilme ve bilimsel süreç becerilerinin gelişmesine katkıda bulunduğunu, ayrıca okulun imajını olumlu yönde etkilediğini ifade etmiştir.

Bilim fuarlarının olumlu yanları olduğu gibi yaşanan birtakım sorunlar da söz konusudur. Örneğin, öğretmenlerin proje geliştirme sırasında rehberlik ederken yaşadığı çeşitli sorunları vardır. Bunlar; proje konusu belirleme, proje raporu yazımında yaşanan sorunlar, kaynak ve zaman yetersizliği ve yöneticilerin proje yapılması konusundaki baskıları olarak belirlenmiştir (Timur ve İmer Çetin, 2017). Kanada' da yapılan bir araştırmada, bilim fuarına katılmanın uzun ve zorlayıcı bir süreç olması, bu süreçten sonra ödül kazanmak için öğrencilerin daha yoğun bir incelemeye maruz kalmaları ve katılan öğrencilerin üniversite programlarına ve şirketlere eleman seçimi gibi bir amaçla fuarların kullanımı gibi olumsuz yönler ortaya konmuştur (Bencze ve Bowen, 2009). Amerika'da yapılan bir araştırmada ise, lise öğrencilerinin yarışma gerektiren bilim fuarlarına yönelik olumsuz görüşleri olduğu belirtilmiştir. Yarışma içeren ve içermeyen bilim fuarlarına yönelik tutumlar arasında ise yarışma içermeyen bilim fuarı lehine olumlu tutumlar tespit edilmiştir (Grinnell, Dalley, Shepherd ve Reisch, 2018). Diğer yandan, 9-16 yaş aralığında öğrencilerin katıldığı bilim fuarında öğrenciler fuarı eğlenceli bulduklarını, yeni şeyler öğrendiklerini ve arkadaşlarıyla çalışma imkânı bulduklarını ifade etmelerine rağmen bazı katı kurallardan, öğretmenleri ile aralarındaki koordinasyon eksikliğinden ve okulları tarafından 
onurlandırılmadıklarından yakınmışlardır (Korkmaz, 2012). Bunun yanında maddi imkânsızlıkların da bilim fuarı çalışmalarında öğrencilerin performanslarını etkilediği rapor edilmiştir (Mupezeni ve Kriek, 2018). Bilim fuarında proje hazırlama çalışmalarında, özellikle küçük yaşlardaki öğrenciler, bilimsel yöntemleri kullanmada zorluk çekmektedir (Chen, Lin, Hsu ve Lee, 2011). Bu yüzden proje geliştirme aşamaları boyunca öğrenciler danışman öğretmenlerinin yardımına ihtiyaç duyarlar. Fen bilgisi öğretmen adaylarının gerçekleştirdikleri bir bilim şenliğinin, akademik başarılar ve bilimsel inanışlar üzerine olumlu katkısı olduğu gösterilmiştir (Yavuz, Büyükekşi ve Büyükekşi, 2014). Bilim festivaline katılan ziyaretçilerin de, etkinlikler hakkında pozitif bakış açısına sahip olduğu görülmüştür (Kızılcık, Çağan, Ünlü Yavaş, 2018). Bilim fuarı ziyaretçileri bilime yönelik ilgi ve bilgi oluşturması açısından da bu fuarları yararlı bulmaktadır (Jensen ve Buckley, 2014).

Yapılan çalışmalar, ilgi, motivasyon ve tutumların öğrenci başarısına etkisi olduğunu göstermektedir (Häussler ve Hoffmann, 2000; Siegel ve Ranney, 2003; Ünlü ve Ertekin, 2017). Bilimin popüler olmasının da tutumlara olumlu etkisi olduğu bilinmektedir (Christidou, 2011). Bu bakımdan bilim fuarlarının bilime yönelik tutumları ve dolayısıyla öğrenci başarılarını olumlu etkilediği açıktır. Kanada'da öğrencilerin bilim fuarlarına katılma nedenleri üzerine yapılan bir çalışmada beş motivasyon kaynağı belirlenmiştir. Bunlar; bilimin içeriğine ilgi, özyeterlik duygusu, ödül veya başarı yoluyla başarı garantisi, katılımcıların sosyal yönü ve edinilen öğrenme stratejileridir (Dionne ve diğ., 2012). Madrid'de yapılan bilim fuarında katılımcıların en önemli motivasyonu, halkın bilime ilgisini ve bilimsel kültürünü arttırmak, bilim ve bilim insanları hakkında farkındalık yaratmak olduğu belirlenmiştir (Martin-Sempre, Garzon-Garcia ve Rey-Racha, 2008). Ortaokul öğrencilerinin bilim şenliklerine yönelik tutumlarının ölçülmesi amacıyla geliştirilen ölçeğin, bilim şenliklerinin; kişisel gelişime katkı sağlaması, ilgi çekici olması ve sosyal yaşama etkisi şeklinde üç faktörlü bir yapıya sahip olduğu görülmüştür (Keçeci, Kırbağ Zengin ve Alan, 2017). Bilim fuarlarının, lise öğrencilerinin kimya alanına yönelik tutumlarını (Şahin, 2012) ve ortaokul öğrencilerinin fen alanına yönelik tutumlarını (Durmaz, Oğuzhan Dinçer ve Osmanoğlu, 2017) arttırdığı da gösterilmiştir.

\section{Araştırmanın Amacı}

Çalışmanın amacı, bilim fuarına proje hazırlama ve sunma sürecinin lise öğrencilerinin fizik dersine yönelik tutumlarına katkısı olup olmadığını araştırmaktır. Böylelikle, bilim fuarlarının fizik dersine yönelik tutumlarına etkisinin olumlu mu yoksa olumsuz mu olduğu ve bu etkinin ne düzeyde olduğunun belirlenebilmesi amaçlanmaktadır. 


\section{Araştırmanın Önemi}

Bilim fuarlarının öğrencilerin derslerine yönelik tutumlarının değişimini araştıran bazı çalışmalar vardır. Bilim şenliğine aktif olarak katılan 6. sınıf öğrencilerinin, fen bilimleri dersine yönelik tutumlarının arttı̆̆ 1 ve üç ay sonra bu tutum seviyelerinin korunduğu bulunmuştur. Bu araştırma bilim şenliklerinin fen dersine yönelik olumlu tutum geliştirmede etkili olduğunu göstermiştir (Yıldırım ve Şensoy, 2016). Fen bilgisi öğretmen adayları ile yapılan bir araştırmada, öğretmen adaylarının bilim fuarı etkinliğinde görev almalarının, öğretim becerilerinin gelişmesine ve fen öğretimine yönelik olumlu tutumlar geliştirmelerine katkıda bulunduğu ortaya konmuştur (Durmaz, Oğuzhan Dinçer ve Osmanoğlu, 2017).

Alanyazında değişik boyutlardaki olumlu ve olumsuz etkileri çeşitli araştırmalarla incelenen bilim fuarlarına katılan lise öğrencilerinin, fizik dersine karşı tutumlarını etkileyip etkilemediğine ve etkiliyorsa ne yönde etkilediğine yönelik araştırma sayısı oransal olarak sınırlıdır. Bu araştırma, bu durumdan yola çıkarak, TÜBİTAK 4006 Bilim Fuarı'na, hazırladığı projesiyle katkıda bulunan lise öğrencileriyle gerçekleştirilmiştir.

\section{YÖNTEM}

Araştırma deneysel araştırma desenlerinden tek grup ön test-son test desenine uygun olarak yarı deneysel desende gerçekleştirilmiştir. Bu araştırma deseninde katılımcılara deney öncesinde ön test, deney sonrasında son test uygulanır. İki test puanı arasındaki fark, deneyin ne denli etkili olduğunu gösterir (Christensen, Johnson ve Turner, 2015). Burada bilim fuarına ilişkin çalışmaların tümü başlamadan önce ve fuardan sonra ölçüm yapılarak, bilim fuarının fizik dersine karşı tutuma etkisine bakılmıştır.

\section{Araştırma Grubu}

Araştırma grubunu, Ankara ilinde düzenlenen TÜBITTAK Bilim Fuarında görev alan; 9, 10 ve 11. sınıflarda öğrenim gören 33'ü kadın, 59'u erkek, toplam 92 lise öğrencisi oluşturmaktadır. Araştırma, bilim fuarına katılan ve fuarda etkin görev alan öğrencileri incelemeyi amaçladığından, araştırmada amaçlı örnekleme yöntemi kullanılmıştır. Öğrenciler bilim fuarında gönüllü olarak görev almak istemişlerdir. Araştırma grubunun demografik yapısı Tablo 1 'de verilmiştir.

Tablo 1.

Araştırma Grubunun Demografik Yapısı

\begin{tabular}{|c|c|c|c|c|c|c|}
\hline \multirow{3}{*}{ Sınıf Düzeyi } & \multicolumn{4}{|c|}{ Cinsiyet } & \multirow{2}{*}{\multicolumn{2}{|c|}{ Toplam }} \\
\hline & \multicolumn{2}{|c|}{ Kadın } & \multicolumn{2}{|c|}{ Erkek } & & \\
\hline & $\mathbf{f}$ & $\%$ & $\mathbf{f}$ & $\%$ & $\mathbf{f}$ & $\%$ \\
\hline 9. sinif & 13 & 14,13 & 35 & 38,04 & 48 & 52,17 \\
\hline 10. sinif & 16 & 17,39 & 11 & 11,96 & 27 & 29,35 \\
\hline 11. sinif & 4 & 4,35 & 13 & 14,13 & 17 & 18,48 \\
\hline TOPLAM & 33 & 35,87 & 59 & 64,13 & 92 & 100,00 \\
\hline
\end{tabular}


Tablo 1'de görüldüğü gibi, katılımcıların yaklaşık \%52 sini 9. sınıf öğrencileri oluşturmaktadır. Ayrıca grupta yaklaşık \%64 oranında erkek öğrenci bulunmaktadır. Tüm öğrenciler Ankara' daki bir fen lisesinde öğrenim görmektedir.

\section{Ölçme Aracı}

Bu makalenin yazarlarının başka bir çalışmada geliştirdiği, lise öğrencilerinin fizik dersine yönelik tutumlarını ölçmeyi amaçlayan Likert türünde 28 maddeden oluşan ölçek, bu çalışmada ölçme aracı olarak kullanılmıştır (Ünlü Yavaş ve Çağan, 2017). Ölçek; ilgi (Cronbach alfa: 0,881), kayg1 (Cronbach alfa: 0,906), önem (Cronbach alfa: 0,898) ve özyeterlik (Cronbach alfa: 0,707) adlarında dört faktörden oluşmaktadır. Ölçeğin açıkladığı varyans \% 60 'tır. Bu faktörler, sırasıyla; 10, 8, 6 ve 4 adet madde ile ölçülmektedir. Ölçek bir lisansüstü tez çalışması kapsamında geliştirilmiş olup geçerlilik ve güvenilirlik çalışmaları söz konusu çalışmada yapılmıştır (Çağan, 2017).

\section{Verilerin Toplanması}

Lise öğrencilerinin fizik dersine yönelik tutumlarını belirleyen ölçek, 2015 yılında bir Fen Lisesinde gerçekleştirilen TÜBİTAK 4006 Bilim Fuarı ile ilgili ön hazırlık çalışmaları başlamadan dört ay kadar önce, 92 lise öğrencisine ön test olarak uygulanmıştır. İlgili ölçek, fuar hazırlıkları tamamlandıktan ve fuar etkinliği gerçekleştirildikten sonraki hafta aynı öğrenci grubuna son test olarak uygulanmıştır. Fuar süreci şu şekilde olmuştur:

Fuar ile ilgili çalışmalar fuarın yapılacağı tarihten dört ay önce başlamıştır. Fuara katılacak öğrenciler belirlendikten sonra araştırma grubu olarak seçilen 92 öğrenciye ön test uygulanmıştır. Ardından öğrencilere sürecin nasıl işleyeceği anlatılmıştır. Öğrenciler öğretmen rehberliğinde ve kendi tercihleri de göz önüne alınarak gruplara ayrılmıştır. Bazı gruplar ikişerli, bazı gruplar ise üçerlidir. Öğrenciler fuarda sunumunu yapacakları konuları kendileri belirlemişlerdir. Bu konuda öğretmen yalnızca rehberlik yapmıştır. Her hafta belirlenen bir saatte öğretmen rehberliğinde düzenli olarak toplantılar düzenlenmiştir. Öğrenciler, öncelikle çevrimiçi kaynaklardan tarama yapmış, grupları için bir proje konusu belirlemiş, projeyi geliştirmek için gereken malzemeleri de kendileri temin etmişlerdir. Araştırma grubu olarak seçilen 92 öğrencinin oluşturduğu grupların tümü fizik ile ilgili projeler geliştirmişlerdir. Öğrenciler süreç içerisinde danışman görevinde bulunan öğretmenlerle gruplar halinde görüşmüş ve danışmanlarının rehberliğinde çalışmalarına yön vermişlerdir. Bu sırada aralarında görev paylaşımı yapmışlardır. Bu projelere örnek olarak “Gökyüzünde Ne Var?” ve “Okul Bahçesinde Güneş Saati” projeleri verilebilir. Öğrencilerin bu projeleri seçme sebebi okullarında bulunan teleskop sistemi ve astronomiye olan ilgileridir. 
Fuar tarihinden bir hafta önce fuarın yapılacağı ilçede bulunan resmi dairelere ve okullara öğrenciler tarafından hazırlanan fuar davetiyeleri, yine öğrenciler tarafından dağıtılmıştır. Söz konusu resmi dairelere ve okullara herkesin görebileceği şekilde fuar afişleri asılmıştır. Açılıştan önce öğrenciler projelerini ve projelerini tanıtan afişleri kendilerine gösterilen stantlarda sergilemeye hazır hale getirmişler ve açılıştan sonra kendi masasına gelen her ziyaretçiye hazırladığı projeyi sunmuş ve ziyaretçilerin sorularını yanıtlamışlardır. Fuar üç gün boyunca sürmüştür. Fuarın bitiminden sonraki hafta fuara katılan öğrencilere son test uygulanmış ve böylece süreç tamamlanmıştır.

\section{Verilerin Analizi}

Likert tipinde elde edilen veriler, en olumsuz tutumdan en olumluya doğru 1-5 arasında derecelendirilerek sayısallaştırılmıştır. Örneğin kaygıyı artıran bir ifadeye verilen puan ters çevrildiğinde puan 5'e yaklaştıkça kaygı artmış, 1'e yaklaştıkça düşmüştür. Elde edilen veriler, bilgisayar yazılımları (SPSS ve MS Excel) yardımıyla incelenmiştir. Yapılan KolmogorovSmirnov normallik analizi sonucunda öntest için anlamlılık değeri 0,38 olarak, son test için ise anlamlılık değeri 0,618 olarak bulunmuş ve dolayısıyla verilerin normal dağılım gösterdiği belirlenmiştir. Bu nedenle ölçeği oluşturan; ilgi, kaygı, önem ve özyeterlik boyutlarında, öğrencilerin tutumlarında süreç sonunda bir değişiklik olup olmadığına karar vermek için eşleştirilmiş iki grup $t$ testi, eşleştirilmiş iki grup korelasyonları ve MANOVA analizlerinden yararlanılmıştır. Böylece her bir faktör için ayrı ayrı sonuçlar ve öğrencilerin cinsiyet ve sınıf düzeyi değişkenlerine bağlı olarak sonuçlar $p=0,05$ anlamlılık düzeyine göre ön test ve son test verileri karşılaştırılmıştır.

\section{BULGULAR}

İlk olarak, öğrencilerin ön testte ve son testte ölçeğin maddelerine verdikleri yanıtların ortalamaları belirlenmiştir. İlgili veriler Tablo 2'de sunulmuştur. 
Tablo 2.

Ölçek Maddelerinin Ön Test ve Son Test Ortalamaları ve Değişim Miktarları

\begin{tabular}{|c|c|c|c|c|c|}
\hline Faktör & $\begin{array}{l}\text { M. } \\
\text { No }\end{array}$ & Madde & $\begin{array}{c}\text { Ön test } \\
\text { Ortalama }\end{array}$ & $\begin{array}{c}\text { Son test } \\
\text { Ortalama }\end{array}$ & $\begin{array}{l}\text { Değișim } \\
\text { Miktarı }\end{array}$ \\
\hline \multirow{11}{*}{.0} & 1 & Fizik dersi zevklidir. & 3,42 & 3,59 & 0,17 \\
\hline & 2 & $\begin{array}{l}\text { Fizik dersi ile ilgili araç gereçleri incelemekten } \\
\text { hoşlanırım. }\end{array}$ & 4,54 & 3,90 & $-0,64$ \\
\hline & 8 & Fizik dersi ile ilgili kitaplar okumak hoşuma gider. & 2,80 & 3,08 & 0,28 \\
\hline & 9 & Fizik dersi ile ilgili konuşmak hoşuma gider. & 3,26 & 3,34 & 0,08 \\
\hline & 11 & Fizik dersini sevmiyorum. & 2,72 & 3,42 & 0,70 \\
\hline & 17 & Fizik dersi sıkıcıdır. & 3,84 & 3,41 & $-0,43$ \\
\hline & 18 & Fizik dersi ilgi çekicidir. & 3,21 & 3,50 & 0,29 \\
\hline & 20 & $\begin{array}{l}\text { Bilim insanlarının fizikle ilgili buluşları nasıl yaptığını } \\
\text { merak ederim. }\end{array}$ & 3,54 & 3,86 & 0,32 \\
\hline & 23 & Fizik dersi eğlencelidir. & 3,51 & 3,47 & $-0,04$ \\
\hline & 28 & Fizik dersi ile ilgili sorular çözmek bence sıkıcıdır. & 3,58 & 3,51 & $-0,07$ \\
\hline & & Faktör Ortalaması & 3,44 & 3,51 & 0,07 \\
\hline \multirow{9}{*}{ 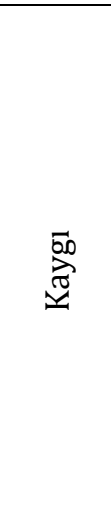 } & 3 & $\begin{array}{l}\text { Fizik dersine ait bir soru ile karşılaştığımda } \\
\text { endişelenirim. }\end{array}$ & 2,42 & 3,15 & 0,73 \\
\hline & 10 & Fizik dersi beni kaygılandırır. & 2,93 & 3,29 & 0,36 \\
\hline & 12 & Fizik dersi ile ilgili bana soru sorulmasından çekinirim. & 3,35 & 3,15 & $-0,20$ \\
\hline & 15 & Fizik dersi beni korkutur. & 3,10 & 3,33 & 0,23 \\
\hline & 21 & Fizik dersi işlenirken kendimi gergin hissederim. & 2,97 & 3,47 & 0,50 \\
\hline & 22 & $\begin{array}{l}\text { Fizik dersi ile ilgili sınavlarda sorular çıkması beni } \\
\text { endișelendirir. }\end{array}$ & 3,26 & 3,27 & 0,01 \\
\hline & 24 & Fizik dersine ait soru çözerken tedirgin olurum. & 2,63 & 3,29 & 0,66 \\
\hline & 25 & Fizik dersinde başarısız olmak beni endişelendirir. & 2,41 & 2,48 & 0,07 \\
\hline & & Faktör Ortalaması & 2,88 & 3,18 & 0,30 \\
\hline \multirow{7}{*}{$\underset{\Xi}{\Xi}$} & 7 & Fizik dersi bence gereksiz. & 3,65 & 3,82 & 0,17 \\
\hline & 13 & $\begin{array}{l}\text { Fizik dersinde öğrendiklerimin günlük hayatımı } \\
\text { kolaylaştıracağını düşünürüm. }\end{array}$ & 3,43 & 3,59 & 0,16 \\
\hline & 16 & $\begin{array}{l}\text { Fizik dersine ayırdığım zamanın boşa gittiğini } \\
\text { düșünürüm. }\end{array}$ & 3,89 & 3,64 & $-0,25$ \\
\hline & 19 & $\begin{array}{l}\text { Yetkim olsa fizik dersini lise müfredatından } \\
\text { çlkartırdım. }\end{array}$ & 3,30 & 3,58 & 0,28 \\
\hline & 26 & Fizik dersini günlük hayatla ilişkili bulurum. & 3,87 & 3,74 & $-0,13$ \\
\hline & 27 & $\begin{array}{l}\text { Bilimsel okuryazarlık için fizik dersini almak bence } \\
\text { gereksiz. }\end{array}$ & 3,32 & 3,78 & 0,46 \\
\hline & & Faktör Ortalaması & 3,58 & 3,69 & 0,12 \\
\hline \multirow{6}{*}{ 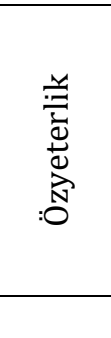 } & 4 & Fizik dersine ait formülleri bilirim. & 3,38 & 3,37 & $-0,01$ \\
\hline & 5 & $\begin{array}{l}\text { Fizik dersini anlayabilmek için yeterli matematik } \\
\text { bilgisine sahibim. }\end{array}$ & 3,59 & 3,70 & 0,11 \\
\hline & 6 & Fizik dersi ile ilgili soruları çözebilirim. & 3,61 & 3,29 & $-0,32$ \\
\hline & 14 & Fizik dersini başarmak için ezber yeteneğim yeterlidir. & 3,54 & 3,62 & 0,08 \\
\hline & & Faktör Ortalaması & 3,53 & 3,50 & $-0,04$ \\
\hline & & Genel Ortalama & 3,32 & 3,45 & 0,13 \\
\hline
\end{tabular}

Tablo 2 incelendiğinde, 28 maddenin 9 tanesinde değişimin negatif, 19 tanesinde ise pozitif yönde olduğu görülmektedir. İlgi boyutundaki 10 maddenin 4'ü negatif, 6'sı pozitif; kayg1 
boyutundaki 8 maddenin yalnızca 1 tanesi negatif, diğerleri pozitif; önem boyutundaki 6 maddenin 2'si negatif, 4'ü pozitif ve özyeterlilik boyutundaki 4 maddenin 2'si pozitif 2'si ise negatif yönde değişim göstermiştir.

Ölçekte yer alan maddelerdeki değişime tek tek bakmak yerine, her bir boyut için istatistiksel açıdan değişime bakılmıştır. Bunun için, öğrencilerin ön teste ve son teste vermiş oldukları yanıtlarının boyutlar açısından anlamlı düzeyde bir değişim görülüp görülmediği incelenmiştir. Bunun için, aynı grupta yapılan ön test ve son test karşılaştırmalarında kullanılan eşleştirilmiş iki grup $\mathrm{t}$ testi analizine başvurulmuştur. Söz konusu veriler Tablo 3 'te görülmektedir.

Tablo 3.

Eşleştirilmiş İki Grup T Testi Sonuçları

\begin{tabular}{|c|c|c|c|c|c|c|}
\hline Faktör & Test & Ortalama & $\begin{array}{c}\text { Standart } \\
\text { Sapma }\end{array}$ & $\begin{array}{c}\text { Serbestlik } \\
\text { Derecesi }\end{array}$ & $\mathbf{t}$ & Anlamlılık \\
\hline İlgi & Ön test & 3,44 & 0,74 & 91 & $-0,527$ & 0,599 \\
\hline Kaygı & $\begin{array}{l}\text { Son test } \\
\text { Ön test }\end{array}$ & $\begin{array}{l}3,51 \\
2,88\end{array}$ & $\begin{array}{l}1,01 \\
0,88\end{array}$ & & & \\
\hline & Son test & 3,18 & 0,99 & 91 & $-2,086$ & 0,040 \\
\hline Önem & $\begin{array}{l}\text { Ön test } \\
\text { Son test }\end{array}$ & $\begin{array}{l}3,58 \\
3,69\end{array}$ & $\begin{array}{l}0,92 \\
1,01\end{array}$ & 91 & $-0,759$ & 0,450 \\
\hline Özyeterlilik & $\begin{array}{l}\text { Ön test } \\
\text { Son test }\end{array}$ & $\begin{array}{l}3,53 \\
3,49\end{array}$ & $\begin{array}{l}0,94 \\
0,70\end{array}$ & 91 & $-0,258$ & 0,797 \\
\hline Genel & $\begin{array}{l}\text { Ön test } \\
\text { Son test }\end{array}$ & $\begin{array}{l}3,32 \\
3,45 \\
\end{array}$ & $\begin{array}{l}0,64 \\
0,92 \\
\end{array}$ & 91 & $-1,087$ & 0,280 \\
\hline
\end{tabular}

Tablo 3'te görüldüğü gibi, testin boyutları içinde yalnızca "kaygı" boyutundaki değişim istatistiksel olarak anlamlıdır $(t(91)=-2,09 ; p<0,05)$. "Kaygı" boyutundaki değişim için Cohen's d etki büyüklüğü hesaplanmış ve 0,22 değeri bulunmuştur. Genel olarak, 0,20'den küçük ise küçük, 0,20-0,50 arasında ise orta, 0,50-0,80 arasında ise büyük etki büyüklüğü olduğu söylenir (Cohen, 1988). Kısacası, öğrenciler süreç sonunda, sürecin başındakine göre fizik dersine ilişkin anlamlı ölçüde daha az kaygı duymaktadırlar. Bu anlamlı farkın etkisi orta düzeyde olmakla birlikte küçük düzeye yakındır. Buna göre, TÜBİTAK Bilim Fuarı için yapılan çalışmaların fizik dersine karşı kaygıyı anlamlı ölçüde azaltsa da etkisinin küçük olduğu söylenebilir. Bu durum, öğrencilerin fizikle ilgili bir etkinliği başarmış olmalarından ve dolayısıyla fizik dersinde başarılı olabileceklerine olan inançlarındaki artıştan ileri gelmiş olabilir.

Öğrencilerde görülen değişimin nasıl olduğunu incelemek için ön test ve son test verilerinin korelasyonuna bakılmıştır. Böylelikle her bir faktör için ön test ve son test puanları arasındaki değişimin ilişkili olup olmadığı incelenmek istenmiştir. Söz konusu veriler Tablo 4'te sunulmuştur. 
Tablo 4.

Eşleştirilmiş İki Grup Korelasyon Sonuçları

\begin{tabular}{|c|c|c|c|c|c|}
\hline Faktör & Test & Ortalama & Standart Sapma & $\mathbf{r}$ & Anlamlılık \\
\hline \multirow[t]{2}{*}{ İlgi } & Ön test & 3,44 & 0,74 & \multirow{2}{*}{0,108} & \multirow{2}{*}{0,303} \\
\hline & Son test & 3,51 & 1,01 & & \\
\hline \multirow[t]{2}{*}{ Kaygı } & Ön test & 2,88 & 0,88 & \multirow{2}{*}{$-0,051$} & \multirow{2}{*}{0,632} \\
\hline & Son test & 3,18 & 0,99 & & \\
\hline \multirow[t]{2}{*}{ Önem } & Ön test & 3,58 & 0,92 & \multirow{2}{*}{$-0,086$} & \multirow{2}{*}{0,416} \\
\hline & Son test & 3,69 & 1,01 & & \\
\hline \multirow[t]{2}{*}{ Özyeterlilik } & Ön test & 3,53 & 0,94 & \multirow{2}{*}{$-0,267$} & \multirow{2}{*}{0,010} \\
\hline & Son test & 3,49 & 0,70 & & \\
\hline \multirow[t]{2}{*}{ Genel } & Ön test & 3,32 & 0,64 & \multirow{2}{*}{0,002} & \multirow{2}{*}{0,983} \\
\hline & Son test & 3,45 & 0,92 & & \\
\hline
\end{tabular}

Tablo 4'e göre, testin boyutları içinde yalnızca “özyeterlilik” boyutundaki veriler istatistiksel olarak anlamlı düzeyde ilişkilidir $(r=0,27)$. Kısacası, öğrenciler için sürecin başında ve sonunda özyeterlilik açısından ölçek sonuçları anlamlı düzeyde ilişkilidir. Bu anlamlı olmasına karşın ilişki düşük düzeydedir. Buna göre, TÜBİTAK Bilim Fuarı için yapılan çalışmalar, öğrencilerde özyeterlilik açısından benzer bir değişime neden olmuştur denebilir. Bu değişim, ön test lehinedir. Kısacası, özyeterlilikte genel olarak azalma görülmektedir. Görülen azalma, tüm öğrencilerde anlamlı biçimde benzerlik göstermektedir ancak azalma miktarı anlamlı düzeyde değildir. Oysa ölçeğin diğer boyutlarında ve genelinde görülen değişimler tüm öğrencilerde anlamlı düzeyde benzerlik göstermemiştir.

Bir sonraki aşamada öğrencilerin ön teste ve son teste verdikleri yanıtların, ölçeğin faktörleri açısından, cinsiyete göre anlamlı düzeyde bir değişim gösterip göstermediği incelenmiştir. Bunun için MANOVA analizi yapılmıştır. Cinsiyete göre faktörler için yapılan analizlere ilişkin bulgular Tablo 5'te verilmiştir.

Tablo 5.

Cinsiyete Göre Faktörler İçin Yapılan MANOVA Sonuçları

\begin{tabular}{|c|c|c|c|c|c|c|c|c|c|c|}
\hline \multirow{2}{*}{ Nicelik } & \multicolumn{2}{|c|}{ İlgi } & \multicolumn{2}{|c|}{ Kaygı } & \multicolumn{2}{|c|}{ Önem } & \multicolumn{2}{|c|}{ Özyeterlilik } & \multicolumn{2}{|c|}{ Genel } \\
\hline & $\mathbf{K}$ & $\mathbf{E}$ & $\mathbf{K}$ & $\mathbf{E}$ & $\mathbf{K}$ & $\mathbf{E}$ & $\mathbf{K}$ & $\mathbf{E}$ & $\mathbf{K}$ & $\mathbf{E}$ \\
\hline $\mathrm{N}$ & 33 & 59 & 33 & 59 & 33 & 59 & 33 & 59 & 33 & 59 \\
\hline Ön Test Ortalama & 3,22 & 3,56 & 2,62 & 3,03 & 3,25 & 3,76 & 3,52 & 3,54 & 3,01 & 3,45 \\
\hline Ön Test Std. Sp. & 0,81 & 0,68 & 0,72 & 0,93 & 0,85 & 0,90 & 0,63 & 0,75 & 0,59 & 0,64 \\
\hline Son Test Ortalama & 3,54 & 3,49 & 3,31 & 3,11 & 3,67 & 3,70 & 3,39 & 3,55 & 3,48 & 3,43 \\
\hline Son Test Std. Sp. & 1,03 & 1,01 & 1,00 & 0,99 & 0,97 & 1,04 & 1,00 & 0,91 & 0,94 & 0,92 \\
\hline Ortalama Farkl & 0,32 & $-0,07$ & 0,69 & 0,08 & 0,42 & $-0,06$ & $-0,13$ & 0,01 & 0,47 & $-0,02$ \\
\hline Box's M Anl. & \multicolumn{2}{|c|}{0,125} & \multicolumn{2}{|c|}{0,509} & \multicolumn{2}{|c|}{0,004} & \multicolumn{2}{|c|}{0,242} & \multicolumn{2}{|c|}{0,178} \\
\hline $\begin{array}{l}\text { Wilks' Lambda / } \\
\text { Pillai's Trace }\end{array}$ & \multicolumn{2}{|c|}{0,948} & \multicolumn{2}{|c|}{0,941} & \multicolumn{2}{|c|}{0,075} & \multicolumn{2}{|c|}{0,992} & \multicolumn{2}{|c|}{0,930} \\
\hline $\mathrm{F}$ & \multicolumn{2}{|c|}{2,43} & \multicolumn{2}{|c|}{2,78} & \multicolumn{2}{|c|}{3,60} & \multicolumn{2}{|c|}{0,36} & \multicolumn{2}{|c|}{3,37} \\
\hline Anlamlılık & \multicolumn{2}{|c|}{0,094} & \multicolumn{2}{|c|}{0,067} & \multicolumn{2}{|c|}{0,031} & \multicolumn{2}{|c|}{0,700} & \multicolumn{2}{|c|}{0,039} \\
\hline Eta Kare & \multicolumn{2}{|c|}{0,052} & \multicolumn{2}{|c|}{0,059} & \multicolumn{2}{|c|}{0,075} & \multicolumn{2}{|c|}{0,008} & \multicolumn{2}{|c|}{0,070} \\
\hline
\end{tabular}

Tablo 5 incelendiğinde, “Önem” faktörü dışındaki hiçbir faktörde anlamlılık değerinin p $\leq$ 0,05 koşulunu sağlamadığ1 görülmektedir. Bu durumda ön test ve son test sonuçları arasında cinsiyete göre "Önem" faktörü dışındaki faktörlerde anlamlı bir fark olmadı̆̆ı söylenebilir. 
Ortalama farklarına bakıldığında, "Önem” faktörü için değişimin kadın öğrenciler lehine olduğu görülmektedir. Çünkü kadın öğrencilerin ön test ve son test ortalama farkları pozitif yönde, erkek öğrencilerin ise negatif yöndedir. Bu durum, ön test ve son test arasında kadın öğrencilerin lehine bir değişim olduğunu göstermektedir. Box's testi sonucu elde edilen anlamlılık değeri, $p>0,05$ olduğunda Wilks' Lambda değeri ve ona bağlı olan diğer veriler kullanılabilir. Burada "Önem" faktörü dışındaki tüm faktörlerde bu değerin 0,05 'ten büyük olduğu gözlenmektedir. Box's testi sonucunda elde edilen anlamlılık değeri 0,05 'ten küçük olması durumunda ise Pillai's Trace değeri ve ona bağlı olan diğer değerler kullanılmalıdır. "Önem” faktörü için Pillai's Trace değeri, diğerleri için ise Wilks' Lambda değeri kullanılmıştır. Bu durumda etki büyüklüğü olan Eta Kare değerine bakıldığında, "Önem" faktörü için değişimin \%7,5'i grup değişkeni tarafından açıklanmaktadır diyebiliriz. Ölçeğin geneline bakıldığında ise $p=0,039$ olduğundan anlamlı bir fark olduğu görülmektedir. Etki büyüklüğü olan Eta Kare değerine bakıldığında, ölçeğin genel sonuçlarındaki değişimin \%7'si grup değişkeni tarafından açıklanmaktadır.

Daha sonra öğrencilerin ön teste ve son teste verdikleri yantların, ölçeğin faktörleri açısından, sınıf düzeyine göre anlamlı düzeyde bir değişim gösterip göstermediği incelenmiştir. Yapılan MANOVA analizlerine ait veriler Tablo 6' da görülmektedir.

Tablo 6.

Sinıf Düzeyine Göre Faktörler İçin Yapılan MANOVA Sonuçları

\begin{tabular}{|c|c|c|c|c|c|c|c|c|c|c|c|c|}
\hline & \multicolumn{3}{|c|}{ İlgi } & \multicolumn{3}{|c|}{ Kaygı } & \multicolumn{3}{|c|}{ Önem } & \multicolumn{3}{|c|}{ Özyeterlilik } \\
\hline & 9 & 10 & 11 & 9 & 10 & 11 & 9 & 10 & 11 & 9 & 10 & 11 \\
\hline $\mathrm{N}$ & 48 & 27 & 17 & 48 & 27 & 17 & 48 & 27 & 17 & 48 & 27 & 17 \\
\hline Ön Test Ort. & 3,73 & 3,20 & 3,03 & 2,74 & 2,90 & 3,29 & 3,86 & 3,33 & 3,17 & 3,51 & 3,50 & 3,65 \\
\hline Ön Test Std. Sp. & 0,61 & 0,76 & 0,74 & 0,89 & 0,79 & 0,90 & 0,83 & 0,92 & 0,91 & 0,72 & 0,78 & 0,55 \\
\hline Son Test Ort. & 3,60 & 3,14 & 3,82 & 3,28 & 2,93 & 3,32 & 3,72 & 3,44 & 4,02 & 3,58 & 3,38 & 3,44 \\
\hline Son Test Std. Sp. & 0,95 & 1,15 & 0,83 & 1,03 & 1,03 & 0,78 & 0,89 & 1,22 & 0,90 & 0,84 & 1,08 & 1,00 \\
\hline Ortalama Farkı & $-0,13$ & $-0,06$ & 0,79 & 0,54 & 0,03 & 0,03 & $-0,14$ & 0,11 & 0,85 & 0,07 & $-0,12$ & $-0,21$ \\
\hline Box': & & 0,538 & & & 0,461 & & & 0,308 & & & 0,376 & \\
\hline Wilks' Lambda & & 0,782 & & & 0,918 & & & 0,854 & & & 0,984 & \\
\hline $\mathrm{F}$ & & 5,76 & & & 1,92 & & & 3,63 & & & 0,35 & \\
\hline Anlamlılık & & 0,000 & & & 0,110 & & & 0,007 & & & 0,845 & \\
\hline Eta Kare & & 0,116 & & & 0,042 & & & 0,076 & & & 0,008 & \\
\hline
\end{tabular}

Tablo 6 incelendiğinde, "İlgi" ve "Önem" faktörü dışındaki faktörlerde anlamlılık değerinin $\mathrm{p} \leq 0,05$ koşulunu sağlamadığı görülmektedir. Bu durumda ön test ve son test sonuçları arasında sınıf düzeyine göre yalnızca "İlgi" ve "Önem" faktörlerinde anlamlı bir fark olduğu söylenebilir. Ortalama farklarına bakıldığında, hem "İlgi” faktörü hem de "Önem” faktörü için değişimin daha üst sınıftaki öğrenciler lehine olduğu görülmektedir. Box's testi sonucu elde edilen anlamlılık değeri, $p \geq 0,05$ olduğunda Wilks' Lambda değeri ve ona bağlı olan diğer veriler kullanılabilir. Bu durumda etki büyüklüğü olan Eta Kare değerine bakıldığında, "İlgi” faktörü için değişimin \%11,6'sı, “Önem” faktörü için ise değişimin \%7,6'sı grup değişkeni tarafından açıklanmaktadır diyebiliriz. 


\section{TARTIŞMA VE SONUÇ}

Ölçek maddelerinin ön test ve son test puan ortalamalarındaki değişim genel olarak pozitif yöndedir. Tutum ölçeğinin dört boyutundan (ilgi, kayg1, önem ve özyeterlik) sadece kayg1 boyutundaki değişim istatistiksel olarak anlamlıdır. Yani öğrencilerin fizik dersine yönelik kaygılarında anlamlı ölçüde azalma gerçekleşmiştir.

$\mathrm{Bu}$ çalışmanın genel sonuçları, bilim fuarlarının öğrencilerin fen derslerine yönelik tutumlarının değişimini araştıran bazı çalışmalarla uyumsuzluk göstermektedir. Çünkü araştırma bulgularında, genel tutum puanları arasında anlamlı bir fark bulunamamıştır. Buna karşın, Yıldırım ve Şensoy'un (2016) benzer etkinliklere katılan 6. sınıf öğrencilerinin, fen bilimleri dersine yönelik tutumlarının arttığı ve üç ay sonra bu tutum seviyelerinin korunduğunu gösteren çalışması örnek verilebilir. Bilim şenliklerinin öğrencilerin derse yönelik tutumlarının gelişimi üzerinde olumlu etkileri olduğu görülmektedir (Crompton ve McKay, 1997; Durmaz, Dinçer ve Osmanoğlu, 2017; Şahin, 2012; Yıldırım, Şensoy, 2016; Yıldırım, 2020). Ayrıca, öğrenciler genellikle bilim fuarlarını zevkli ve eğlenceli olarak nitelendirmektedir (Okuyucu, 2019; Sontay, Anar ve Karamustafaoğlu, 2019; Yıldırım, 2020).

Araştırma bulgularına göre, özyeterlilik boyutunda, ön test ve son test verileri arasında anlamlı bir korelasyon vardır. Ancak ön test ve son test verileri arasındaki fark anlamlı değildir. Öğrenciler bilim fuarı hazırlıkları sırasında arkadaşları ve danışman öğretmeniyle birlikte bilimsel bir çalışma yürütmüştür. Sık sık bir araya gelmiş ve hazırlık sürecini işbirliği ve görev paylaşımı yaparak geçirmişlerdir. Bu tür etkinlikler aracılığı ile, bilimin doğası ve bilim hakkında daha kapsamlı anlamaya sahip olmanın, bilim öğrenmeye yönelik kaygıları azaltmaya ve özyeterliğin artmasına katkısı olduğu belirtilmektedir (van Aalderen-Smeets ve van der Molen, 2015). Deneyimli kimya öğretmenleri ile yapılan bir çalışmada ise TÜBİTAK bilim fuarlarının öğrencilerin hem birlikte başarma duyguların geliştirdiği hem de özgüvenlerini artırdığı yönünde görüş belirtmişlerdir (Kural ve Nakiboğlu, 2020). Ayrıca benzer biçimde, bilim fuarlarına katılan öğrencilerde özyeterliliğgin ve özgüvenin arttığını belirten çalışmalar mevcuttur (Avcı ve diğ., 2016; Başar, 2018). Bilim fuarlarının, ortaokul öğrencilerinin fen derslerine yönelik kaygıları azalttığı gösterilmiştir (Keskin, 2019, Yıldırım, 2020). Bu çalışmalar, araştırmanın kaygı ile ilgili bulguları ile uyumlu olmasına karşın, özyeterlilik ile ilgili bulguları ile uyumsuzdur. Bir başka araştırmada, ortaokul öğrencileriyle yapılan bilim fuarı çalışmalarının, öğrencilerin bilim insanı imajlarında olumlu değişimler oluşturduğu gösterilmiştir (Kahraman, 2019). Ayrıca, bilim fuarlarının öğrencilerin birçok özelliğini (iletişim kurma, işbirlikli çalışma, özgüven sağlama, planlı çalışma, kendini ifade edebilme vb.) artırmada etkili olduğunu gösteren çalışmalar bulunmaktadır (Akpınar ve diğ., 2008, Camcı, 2008). 
Özyeterlik boyutundaki, fizik dersine ait formülleri bilirim (4. madde) ve fizik dersi ile ilgili soruları çözebilirim (6. madde) maddelerindeki değişimin negatif olması, öğrencilerin fizik dersinin formüllü ve sorularla dolu olmasıyla ilgili yapısal sorunları olduğunun yansıması olarak değerlendirilebilir. Fizik dersinde kullanılan soruların niteliği de önemlidir. Öğrenciler geleneksel fizik problemlerine göre günlük hayatlarından ve sosyo-kültürel çevrelerinden bağlamların yer aldığı problemleri daha anlaşılır ve ilgi çekici bulmaktadır (Tekbıyık ve Akdeniz, 2010).

Maddelerin ön test ve son test ortalama değerlerine bakıldığında bazı maddelerde negatif yönde değişim gerçekleştiği görülmüştür. Örneğin, ilgi boyutundaki fizik dersinin sıkıcı (17. Madde), eğlenceli (23. madde) ve soru çözmenin sıkıcı (28. Madde) olması ile ilgili maddelerdeki değişim olumsuz yöndedir. Bu durum, proje hazırlama sırasında kendi çabasıyla ve tasarlayarak öğrenen öğrencilere sınıf ortamında öğretilen dersin sıkıcı gelmesi olarak yorumlanabilir. Çünkü fizik dersinin ilgi çekici olması (18. madde), zevkli olması (1. madde) gibi maddelerdeki değişim pozitif yöndedir. Sınıfta fizik dersinin öğretilmesi ile ilgili teknikler ve öğrenme ortamları hakkında öğrencilerin fikirlerinin alınması bu duruma açıklık kazandıracaktır. Bu araştırmanın bulguları ile uyumsuz olarak, Şahin (2012), kimya derslerine yönelik tutum ile bilim fuarı arasındaki ilişkiyi incelediği çalışmasında, derse ilgisi olmayan bazı öğrencilerin, derslerde daha aktif ve ilgili olduklarını belirtmiştir. Ayrıca, bilim şenliklerinin öğrencilerin ilgilerini artırdığına yönelik araştırmalar da mevcuttur (Bunderson ve Anderson, 1996; Perry, 1995; Yıldırım, 2020).

Benzer şekilde önem boyutundaki fizik dersine ayrılan zamanın boşa gitmesi (16. madde) ve fizik dersinin günlük hayatla ilişkili olması (26. madde) maddelerindeki değişimin negatif çıkması bu durumu destekler niteliktedir. Fizik deneyleri yapmanın öğrencilerin fizik tutumlarını negatif yönde değiştirdiğinin belirtildiği bir araştırmada, tutumların azalmasının sebepleri hakkında görüşleri alınan öğrenciler, teorik dersler ile deneyler arasında bağlantı kuramadıklarını ifade etmişlerdir (Çetin, 2015).

$\mathrm{Bu}$ araştırmanın başka sonuçları olarak, cinsiyet değişkenine göre; önem boyutunda ve genel olarak kadın öğrenciler lehine anlamlı düzeyde bir artış olduğu belirlenmiştir. Oysa yapılan bir araştırmada, bu araştımanın bulgularına tam ters olarak, erkek katılımcıların kadın katılımcılara göre bilim şenliğini ve düzenlenen etkinlikleri daha olumlu bulduğu, bunun nedeninin de bilimin erkeklerle özdeşleştirilmiş olması olduğu belirtilmiştir (Başar ve ark., 2018). $\mathrm{Bu}$ durum, araştırmanın sonuçları ile uyumsuzdur. Burada, öğrencilere birinci düzeyde danışmanlık yapan öğretmenin kadın olmasının etkisi olabilir.

Sınıf düzeyleri değişkenine göre, ilgi ve önem boyutlarında daha üst sınıflardaki öğrencilerin lehine anlamlı bir artış gözlenmiştir. Buna benzer biçimde, Başar ve arkadaşları (2018), bilim şenliğine katılanların yaş ortalaması arttıkça daha olumlu tutum geliştirdiklerini 
belirtmektedir. Genel olarak bilim fuarlarının fen konularına karşı ilgiyi artırdığına yönelik alanyazında ortak bir görüş vardır (Kızılcık ve diğ., 2018; Şahin, 2012; Yıldırım, Şensoy, 2016; Yildırım, 2020).

\section{ÖNERİLER}

$\mathrm{Bu}$ çalışmada bilim fuarının öğrencilerin fizik dersine yönelik tutumlarındaki etkisi incelendi. Fuar çalışmasına katılan öğrencilerin fizik dersine yönelik tutumları yanında fizik alanına ya da bilime yönelik tutumlarının da incelenip karşılaştırılması yapılabilir. Bu karşılaştırma fiziğin öğretilmesine yönelik yapılacak geliştirmelere katkı sağlayabilir. Ayrıca, bu araştırma Ankara' daki bir fen lisesinde gerçekleşmiştir. Araştırma söz konusu örneklemin temsil ettiği evren ile sınırlıdır. Benzer çalışmaların diğer türdeki liselerde ve daha geniş veya farklı evrenleri temsil eden örneklemlerle yapılması, bilim fuarı çalışmalarının öğrenci tutumlarına etkisini ortaya koymak bakımından daha iyi olacaktır. Ayrıca benzer çalışmaların farklı yöntemlerle yapılması, bilim fuarlarının öğrenci tutumlarına etkisinin anlaşılması açısından daha geniş bir bakış açısı sağlayabilir.

\section{KAYNAKÇA}

Akpınar, E., Yıldız, E., Akpınar, D., \& Ergin, Ö. (2008) Fen eğitiminde proje çalışmaları ve bilim şenliklerine yansımaları. Çă̆daş Eğitim Dergisi, 33(351), 14-20.

Avc1, E., \& Su Özenir, Ö. (2018). Bilim fuarları sürecinin yürütücü öğretmenler gözünden değerlendirilmesi. İlköğretim Online, 17(3), 1672-1690.

Avcı, E., Su Özenir, Ö., \& Yücel, E. (2016). TÜBITTAK ortaöğretim öğrencileri araştırma projeleri yarışmasına katılan öğrencilerin yarışma sürecindeki deneyimlerinin üniversite yaşamlarına yansıması, Uşak Üniversitesi Sosyal Bilimler Dergisi, 9(27), 1-21.

Başar, M., Doğan, C., Şener, N., \& Doğan, Z. G. (2018). Bilim şenliği etkinliklerinin öğrenci, veli ve öğretmen görüşlerine göre incelenmesi. Uşak Üniversitesi Sosyal Bilimler Dergisi, 11(2), 132-147. doi: 10.29217/uujss.243.

Bencze, J. L., \& Bowen, G. M. (2009). A national science fair: Exhibiting support for the knowledge economy. International Journal of Science Education, 31(18), 2459-2483, DOI: 10.1080/09500690802398127.

Bunderson, E. D., \& Anderson, T. (1996). Preservice elementary teachers' attitudes toward their past experience with science fairs. School Science and Mathematics, 96(7), 371-377.

Camcı S. (2008). Bilim şenliğine katılan ve katılmayan öğrencilerin bilim ve bilim insanlarına yönelik ilgi ve imajlarının karşılaştırılması. Yayımlanmamış Yüksek Lisans Tezi, Hacettepe Üniversitesi Sosyal Bilimler Enstitüsü, Ankara. 
Chen, J., Lin, H., Hsu, Y., \& Lee, H. (2011). Data and claim: The refinement of science fair work through argumentation. International Journal of Science Education, Part B, 1(2), 147-164.

Christensen, L.B., Johnson, R.B., \& Turner, L.A. (2015). Araştırma yöntemleri desen ve analiz. Çev. Ed. Ahmet Alpay, Ankara: Anı Yayıncılık.

Christidou, V. (2011). Interest, attitudes and images related to science: Combining students' voices with the voices of school science, teachers, and popular science. International Journal of Environmental and Science Education, 6(2), 141-159.

Cohen, J. (1988). Statistical power analysis for the behavioral sciences (2nd Ed.). Taylor \& Francis Group, New York: Routledge.

Crompton J.L., \& McKay, S., L. (1997). Motives of visitors attending festival events. Tourism of Annuals Research, 24 (2)425-439

Çağan, S. (2017). Lise öğrencilerinin fizik dersine ve 10. sınıf bazı fizik konularına yönelik tutumlarının ölçülmesi. Yayınlanmamış Yüksek Lisans Tezi, Ankara: Gazi Üniversitesi.

Çetin, A. (2015). İşbirliğine dayalı öğrenme yöntemine göre planlanan fizik deneylerinin öğretmen adaylarının bilimsel süreç becerilerine ve fizik tutumlarına etkisi. Siirt Üniversitesi Sosyal Bilimler Enstitüsü Dergisi, 4, 154-166.

Dionne, L., Reis, G., Trudel, L., Guillet, G., Kleine L., \& Hancianu, C. (2012). Students' sources of motivation for participating in science fairs: an exploratory study within the Canada-Wide Science Fair 2008. International Journal of Science and Mathematics Education, 10(3), 669-693.

Durmaz, H., Oğuzhan Dinçer, E., \& Osmanoğlu, A. (2017). Bilim şenliğinin öğretmen adaylarının fen öğretimine ve öğrencilerin fene yönelik tutumlarına etkisi. Trakya Üniversitesi Eğitim Fakültesi Dergisi, 7(2), 364-378.

Gomez, K. (2007). Negotiating discourses: Sixth-grade students' use of multiple science discourses during a science fair presentation. Linguistic and Education, 18, 41-64.

Grinnell, F., Dalley, S., Shepherd, K., \& Reisch, J. (2018). High school science fair: Student opinions regarding whether participation should be required or optional and why. PLoS ONE, 13(8): e0202320. https:// doi.org/10.1371/journal.pone.0202320

Häussler, P., \& Hoffmann, L. (2000). A curricular frame for Physics education: Development, comparison with students $^{e e}$ interests, and impact on students ${ }^{e e}$ achievement and selfconcept. Science Education, 84, 689-705.

Jensen, E., \& Buckley, N. (2014). Why people attend science festivals: Inyerests, motivations and self-reported benefits of public engagemant with research. Public Understanding of Science, 23(5), 557-573. 
Kahraman, Ü. (2019). TÜBİTAK 4006 bilim fuarlarının öğrencilerin bilim insanı imajına etkisi A ̆ğr İli örneği. Yayınlanmamış Yüksek Lisans Tezi, Ağrı İbrahim Çeçen Üniversitesi Fen Bilimleri Enstitüsü, Ağr1.

Keskin, D. (2019). Bilim fuarlarının ortaokul öğrencilerinin bilimsel süreç becerileri, fen dersine karşı motivasyonlar ve kaygı düzeyleri üzerinde etkisi. Yayınlanmamış Yüksek Lisans Tezi, Pamukkale Üniversitesi Eğitim Bilimleri Enstitüsü, Denizli.

Kızılcık, H. Ş., Çağan, S., \& Ünlü Yavaş, P. (2018). TÜBİTAK bilim fuarlarına ve fuarların fizik dersine yönelik öğrenci tutumlarına etkisine ilişkin ziyaretçi görüşleri. Amasya Üniversitesi Eğitim Fakültesi Dergisi, 7(2), 287-310.

Keçeci, G., Kırbağ Zengin, F., \& Alan, B. (2017). Bilim şenliği tutum ölçeği: Geçerlilik ve güvenirlik çalışması. International Journal of Eurasia Social Sciences, 8(27), 562-575.

Koomen, M.H., Rodriguez, E., Hoffman, A., Petersen, C., \& Oberhauser, K. (2018). Authentic science with citizen science and student-driven science fair projects. Science Education, 102, 593-644.

Korkmaz, H. (2012). Making science fair: how can we achieve equal opportunity for all students in science? Procedia-Social and Behavioral Sciences, 46, 3078-3082.

Kural, N., \& Nakiboğlu, C. (2020). Deneyimli kimya öğretmenlerinin TÜBİTAK 4006 bilim fuarları destekleme programlarına yönelik düşüncelerinin incelenmesi. Türkiye Kimya Derneği Dergisi Kısım C: Kimya Ĕ̆itimi, 5(1), 71-94. doi: 10.37995/jotcsc.697564

Martin-Sempre, M. J., Garzon-Garcia, B., \& Rey-Rocha, J. (2008). Scientists' motivation to communicate science and technology to the public: surveying participants at the Madrid Science Fair. Public Understanding of Science, 17, 349-367.

Mupezeni, S., \& Kriek, J. (2018). Out-of-school activity: A comparison of the experiences of rural and urban participants in science fairs in the Limpopo Province, South Africa. Journal of Mathematics, Science and Technology Education, 14(8), em1577.

Okuyucu, M.A. (2019). 4006-TÜBİTAK Bilim Fuarına ilişkin öğretmen ve öğrenci görüşleri. International Journal of Social Sciences and Education Research, 5(2), 202-218.

Perry, P. J. (1995). Getting started in science fairs: From planning to judging. Blue Ridge Summit, PA: TAB Books.

Rahm, J., Martel-Reny, M.P., \& Moore, J.C. (2005). The role of afterschool and community science programs in the lives of urban youth. School Science and Mathematics, 105(6), 283-291.

Siegel, M.A., \& Ranney, M.A. (2003). Developing the changes in attitude about the relevance of science (CARS) questionnaire and assessing two high school science classes. Journal of Research in Science Teaching, 40(8), 757-775. 
Şahin, Ş. (2012). Bilim şenliklerinin 10. sını öğrencilerinin kimya dersine yönelik tutumlarına olan etkisi. Uşak Üniversitesi Sosyal Bilimler Dergisi, 5(1), 89-103.

Şahin, A., Ayar, M. C., \& Adıgüzel, T. (2014). Fen, teknoloji, mühendislik ve matematik içerikli okul sonrası etkinlikler ve öğrenciler üzerindeki etkileri. Kuram ve Uygulamada Eğitim Bilimleri, 14(1), 297-322.

Sontay, G., Anar, F., \& Karamustafaoğlu, O. (2019). 4006-TÜBİTAK bilim fuarına katılan ortaokul öğrencilerinin bilim fuarı hakkındaki görüşleri. International e-Journal of Educational Studies (IEJES), 3(5), 16-28.

Tekbıyık, A., \& Akdeniz, A.R. (2010). Bağlam temelli ve geleneksel fizik problemlerinin karşılaştırılması üzerine bir inceleme. Necatibey Eğitim Fakültesi Elektronik Fen ve Matematik Dergisi, 4(1), 123-140.

Timur, B., \& İmer Çetin, N. (2017). Fen ve teknoloji öğretmenlerinin proje geliştirmeye yönelik yeterlikleri: Hizmet içi eğitim programının etkisi. Ahi Evran Üniversitesi Kırşehir Eğitim Fakültesi Dergisi (KEFAD), 18(2), 97-111.

TÜBİTAK (2018). TÜBİTAK bilim fuarları. <https:/ / www.tubitak.gov.tr/tr/destekler/bilim-vetoplum/ulusal-destek-programlari/icerik-4006-tubitak-bilim-fuarlari-desteklemeprogrami> adresinden 12.03.2018 tarihinde alınmıştır.

Ünlü, M., \& Ertekin, E. (2017). A structural equation model for factors affecting eighth graders' geometry achievement. Educational Sciences: Theory \& Practice, 17, 1815-1846.

Ünlü Yavaş, \& P., Çağan, S. (2017). Development of an attitude scale towards high school physics lessons. Journal of Education and Training Studies, 5, 56-66.

van Aalderen-Smeets, S. I., \& Walma van der Molen, J. H. (2015). Improving primary teachers' attitudes towards science by attitude-focused Professional development. Journal of Reserarch in Science Teaching, 52(5), 710-734.

Yavuz, S., Büyükekşi, C., \& Büyükekşi, I. (2014). Bilim şenliğinin bilimsel inanışlar üzerine etkisi. Karaelmas Journal of Educational Sciences, 2, 168.174.

Yıldırım, H. İ., \& Şensoy, Ö. (2016). Bilim şenliklerinin 6. sınıf öğrencilerinin fen bilimleri dersine yönelik tutumlarına etkisi. Türk Eğitim Bilimleri Dergisi, 14(1), 23-40.

Yıldırım, H. İ. (2018). Bilim şenliklerinin ortaokul 6. sınıf öğrencilerinin problem çözme becerilerine etkisi. Trakya Üniversitesi Ĕ̆itim Fakültesi Dergisi, 8(2), 390-409.

Yıldırım, H. İ. (2020). Bilim fuarında projeyle yer alan öğrencilerin ve danışman öğretmenlerin bilim fuarına ilişkin görüşleri. e-Kafkas Eğitim Araştırmaları Dergisi, 7, 28-51. doi:10.30900/kafkasegt.677181. 